BBA 31269

\title{
CHEMICAL CHARACTERIZATION OF BIODEGRADATIVE THREONINE DEHYDRATASES FROM TWO ENTERIC BACTERIA
}

\author{
SOUNG SOO KIM * and PRASANTA DATTA \\ Department of Biological Chemistry, The University of Michigan, Ann Arbor, MI 48109 (U.S.A.)
}

(Received February 2nd, 1982)

Key words: Threonine dehydratase; Biodegradation; (Enteric bacteria)

Some chemical properties of the purified biodegradative threonine dehydratases (L-threonine hydro-lyase (deaminating), EC 4.2.1.16) from Escherichia coli and Salmonella typhimurium are described. The overall amino acid compositions of the two enzymes appear similar with some variations in several amino acid residues. Tryptic peptide maps show that in $S$. typhimurium four peptides of $E$. coli origin are missing, whereas six peptides unique to Salmonella protein are present. Carboxymethylation reaction with iodo $\left[{ }^{14} \mathrm{C}\right]$ acetate to detect half-cystine residues indicates that peptides 21 and S5 in S. typhimurium, but not in $E$. coli enzyme, are labeled, and the reverse is true for peptide 22; four other peptides of $S$. typhimurium have more half-cystine residues than their counterparts in $E$. coli. In addition, the Salmonella enzyme appears to have several disulfide bonds. Despite these differences, the amino acid sequence of the amino termini of the two proteins reveals a highly conserved structure, with only three out of 25 residues being different. Reduction with tritium-labeled borohydride followed by tryptic fingerprinting of the two proteins shows that one peptide contains active-site pyridoxal phosphate. Modifier binding studies with the $S$. typhimurium enzyme indicate that pyruvate and glyoxylate occupy separate sites on the enzyme molecules. Further, there are two distinct sites for glyoxylate binding: in the monoglyoxylated form of the enzyme, only peptide 22 becomes labeled, whereas both peptides 22 and 21 of the tetraglyoxylated form of the dehydratase contain bound glyoxylate. These results support the earlier findings that these two metabolites regulate enzyme activity by two separate, mutually exclusive, mechanisms.

\section{Introduction}

The structure and regulation of biodegradative threonine dehydratase (EC 4.2.1.16) from Escherichia coli and Salmonella typhimurium have been the subject of intensive investigation in recent years. The $E$. coli enzyme has a molecular

\footnotetext{
* Present address: Korean Advanced Institute of Science and Technology, P.O. Box 131, Dong Dae Mun, Seoul, Korea.

Abbreviation: TPCK, L-(tosylamido-2-phenyl)ethyl chloromethyl ketone.
}

weight of 147000 and is composed of four identical subunits of approximately 38000 each [1-3]; there are 4 mol pyridoxal phosphate per $147000 \mathrm{~g}$, and the tetrameric protein can bind $4 \mathrm{~mol}$ AMP per mol protein [2]. The dehydratase of $S$. typhimurium, on the other hand, has a molecular weight of 140000 , consists of four subunits of about 36000 each, and contains $2 \mathrm{~mol}$ bound pyridoxal phosphate per mol enzyme [4]. In the context of metabolic regulation, the enzymes isolated from these organisms are stimulated by AMP [4-6], inhibited by the ketoacids, 2-oxobutyrate, pyruvate and glyoxylate [7-9], and subject to catabolite inactivation by various intermediary metabolites 
$[4,9,10]$, although the exact mechanism varies somewhat depending on the specific protein-ligand interactions. These findings prompted us to examine some of the chemical characteristics of the two proteins in order to understand their molecular organization and regulatory interactions with a variety of cellular metabolites.

\section{Materials and Methods}

Materials. Allo-free L-threonine, sodium salts of pyruvate, glyoxylate and iodoacetate, AMP and dithiothreitol were purchased from Sigma Chemical Company. Sodium $\left[{ }^{14} \mathrm{C}\right]$ pyruvate, sodium $\left[{ }^{14} \mathrm{C}\right]$ glyoxylate, sodium $\left[{ }^{3} \mathrm{H}\right]$ borohydride, and $\left[{ }^{14} \mathrm{C}\right] \mathrm{AMP}$ were bought from Amersham/Searle; iodo $\left[1-{ }^{14} \mathrm{C}\right]$ acetate was purchased from New England Nuclear. Guanidine hydrochloride was purchased from Schwartz-Mann and TPCK-trypsin was from Worthington. Thin-layer cellulose plates were obtained from Analab. All other chemicals were of reagent grade.

Enzyme purification. Biodegradative threonine dehydratases from $E$. coli K12 (ATCC 14948) and $S$. typhimurium LT2 (a gift from Dr. H.J. Whitfield) were purified by affinity chromatography on AMP-Sepharose by the published procedures [4,9]. Enzyme activity was measured spectrophotometrically at $310 \mathrm{~nm}$ [7] as described by Park and Datta [9]. Purity of enzyme preparations was checked routinely by SDS-polyacrylamine gel electrophoresis of reduced and alkylated proteins by the method of Weber et al. [11]; for some experiments reported here, the carboxymethylated proteins were further passaged through Biogel P-100 equilibrated with $6 \mathrm{M}$ guanidine hydrochloride to confirm their purity (see Fig. 1).

Amino acid analysis. Salt-free lyophilized enzyme, prepared by the method of Blackburn [12], was dissolved in glacial acetic acid, hydrolyzed in constant-boiling $6 \mathrm{M} \mathrm{HCl}$ at $110^{\circ} \mathrm{C}$ for various lengths of time and analyzed on a Durrum amino acid analyzer. The number of residues was calculated from the average of duplicate 24-h and 72-h hydrolyses with the following exceptions: the values for valine and isoleucine were obtained from duplicate 72-h hydrolyses, whereas those for threonine and serine were calculated from extrapolation to zero time of hydrolysis. The number of half-cystines was determined by performic acid oxidation of the protein [12] prior to acid hydrolysis. The amounts of tyrosine and tryptophan were determined spectrophotometrically by the method of Bencze and Schmid [13]. All calculations are based on the dry weight of the protein [14].

Carboxymethylation of protein. The reduction and alkylation of the $E$. coli and $S$. typhimurium dehydratases were carried out essentially by the method of Ramachandran and Colman [15]. In brief, $1-10 \mathrm{mg}$ protein were dissolved in $0.5-5 \mathrm{ml}$ of $0.1 \mathrm{M}$ sodium borate buffer, $\mathrm{pH} 8.8$, containing $6 \mathrm{M}$ guanidine hydrochloride and $10 \mathrm{mM}$ EDTA. The solution was made $1 \%$ with respect to 2mercaptoethanol, and reduced in a nitrogen atmosphere for $1 \mathrm{~h}$ at $25^{\circ} \mathrm{C}$. Sodium iodoacetate (final concentration $0.14 \mathrm{M}$ containing $20 \mu \mathrm{Ci}$ of sodium iodo $\left[1-{ }^{14} \mathrm{C}\right]$ acetate) was added and the solution was maintained in the dark for $30 \mathrm{~min}$. After the incubation period, excess 2-mercaptoethanol (10\%, $50 \mu 1)$ was added and the solution was dialyzed against a large excess of deionized water, with several changes, before lyophilization.

Tryptic peptide analysis. For digestion with trypsin, the lyophilized enzyme was dissolved in $0.1 \mathrm{M}$ ammonium bicarbonate, $\mathrm{pH} 8.6$, usually at a concentration of $1 \mathrm{mg} / \mathrm{ml}$ and incubated with TPCK-trypsin $(100: 1 \mathrm{w} / \mathrm{w})$ for $4-6 \mathrm{~h}$ at $37^{\circ} \mathrm{C}$. In some experiments, the incubation was carried out at $30^{\circ} \mathrm{C}$ for $20 \mathrm{~h}$ with a drop of toluene. The digested sample was lyophilized, dissolved in a small volume of deionized water and $200-400 \mu \mathrm{g}$ of protein in 20-30 $\mu \mathrm{l}$ were applied on to a $20 \times 20 \mathrm{~cm}$ cellulose-coated plates $(100 \mu \mathrm{m}$ thickness). Electrophoresis was performed according to the general procedure of Gracy [16] at $800 \mathrm{~V}(300$ $\mathrm{mA}$ ) for $60 \mathrm{~min}$ using a Desaga-TLE doublechamber apparatus cooled to $4^{\circ} \mathrm{C}$ with a Lauda refrigerated cooling system. The buffer system was pyridine/glacial acetic acid/water (300:10:2700), pH 6.4. Chromatographic separation was performed in a solvent system of $n$-butanol/glacial acetic acid/pyridine/water $(90: 18: 60: 72)$ for approx. $4 \mathrm{~h}$. The plates were then dried and stained with the cadmium-ninhydrin reagent [17]. The tryptic fingerprints displayed in Fig. 2 represent a composite map dervied from four independent fingerprints carried out under identical conditions. Automated protein sequencing. Automated Ed- 
man sequence analyses of reduced and alkylated proteins were performed on a Beckman $890 \mathrm{C}$ spinning-cup sequencer equipped with a sequemat autoconverter. No carrier was used with proteins in order to minimize background. The standard Beckman 0.1 M Quadrol program (No. 122974) was modified in several minor ways $[18,19]$. Phenylthiohydantoin-amino acids were separated and quantified isocratically at $50^{\circ} \mathrm{C}$ on a Waters HPLC system consisting of a model $6000 \mathrm{~A}$ pump, Altrex ultrasphere ODS column, model 440 detector (254 $\mathrm{nm}$ ), WISP autoinjector and Data Module. Standard running solvent was $45 \%$ acetonitrile $/ 0.01 \mathrm{M}$ sodium phosphate buffer, $\mathrm{pH} 4.6$; reruns in $62 \%$ acetonitrile were necessary to distinguish between phenylthiohydantoin-alanine and phenylthiohydantoin-tyrosine. Repetitive yield was $93 \%$ up to 25 cycles of Edman degradation.

Nucleotide binding . The binding of $\left[{ }^{14} \mathrm{C}\right] \mathrm{AMP}$ to purified enzyme from $S$. typhimurium was determined by equilibrium dialysis [20] using a multichambered rotary apparatus supplied by MRA Corporation. The stock enzyme solution (0.4 $\mathrm{mg} / \mathrm{ml}$ ), previously dialyzed against freshly prepared $0.1 \mathrm{M}$ potassium phosphate buffer, $\mathrm{pH} 6.8$, containing $3 \mathrm{mM}$ sodium azide and $0.2 \mathrm{mM}$ phenylmethylsulfonyl fluoride, was incubated with varying concentrations of $\left[{ }^{14} \mathrm{C}\right] \mathrm{AMP}(0.039 \mathrm{mM}$ to $0.79 \mathrm{mM}$, spec. act. $650 \mathrm{cpm} / \mathrm{nmol}$ ) at $4^{\circ} \mathrm{C}$ for $16 \mathrm{~h}$ with a gentle rotary motion (approx. $8 \mathrm{rpm}$ ) prior to sampling for radioactivity. Preliminary experiments showed complete equilibration under these conditions. The data are displayed in the form of a Scatchard plot (see Fig. 4) from the average of duplicate samples at each concentration of AMP used.

Borohydride reduction. Reduction of threonine dehydratase with tritium-labeled sodium borohydride was performed according to the method of Fluri et al. [21]. $200 \mu \mathrm{g}$ sodium [ ${ }^{3} \mathrm{H}$ ]borohydride (spec. act. $5 \mathrm{Ci} / \mathrm{mmol}$ ) were added to $5 \mathrm{mg}$ protein in $5 \mathrm{ml} 0.1 \mathrm{M}$ potassium phosphate buffer, $\mathrm{pH} 7.5$, containing $1 \mathrm{mM} 2$-mercaptoethanol and $20 \mu \mathrm{M}$ pyridoxal 5'-phosphate. After incubation for $3 \mathrm{~min}$ at $25^{\circ} \mathrm{C}$, unlabeled borohydride was added to a final concentration of $5 \mathrm{mM}$. The mixture was further incubated for $3 \mathrm{~min}$ at $25^{\circ} \mathrm{C}$ and dialyzed exhaustively against $0.1 \mathrm{M}$ ammonium bicarbonate to remove unbound radioactivity and unreacted borohydride. The solution was lyophilized before digesting with TPCK-trypsin as described above.

Labeling with ${ }^{14} \mathrm{C}$-labeled pyruvate and glyoxylate. The methods for binding of pyruvate and glyoxylate to threonine dehydratase have been published $[9,10]$. Briefly, stock solutions of enzyme $\left(1 \mathrm{mg} / \mathrm{ml}\right.$ ), previously dialyzed at $4^{\circ} \mathrm{C}$ against $0.1 \mathrm{M}$ potassium phosphate buffer, $\mathrm{pH} 8.0$, containing $3 \mathrm{mM}$ AMP, were incubated separately at $4^{\circ} \mathrm{C}$ with $20 \mathrm{mM}$ sodium $\left[{ }^{14} \mathrm{C}\right]$ pyruvate (spec. act. $14.7 \mathrm{mCi} / \mathrm{mmol}$ ) or $20 \mathrm{mM}$ sodium $\left[{ }^{14} \mathrm{C}\right]$-glyoxylate (spec. act. $8.33 \mathrm{mCi} / \mathrm{mmol}$ ) to inactivate the enzyme to greater than $80 \%$. The solutions of inactive enzyme were then dialyzed exhaustively at $4^{\circ} \mathrm{C}$ against a large volume $0.1 \mathrm{M}$ ammonium bicarbonate solution to remove unbound radioactivity, and lyophilized before digestion with trypsin.

Other methods. Protein was determined by the method of Lowry et al. [22] using bovine serum albumin as the standard.

An estimation of the dry weight of the dehydratases was made by the modified biuret reaction [14] using a calibration curve of bovine serum albumin relating dry weights and the differences in absorbance at $390 \mathrm{~nm}$ and $290 \mathrm{~nm}$ (provided by Dr. M.J. Hunter).

Radioactivity was measured using a cocktail of Omnifluor (4 g/litre of toluene) and Triton X-100 $(7 / 3, v / v)$ in a Packard Tricarb spectrometer with a $\left[{ }^{14} \mathrm{C}\right]$ toluene standard to determine counting efficiency.

\section{Results and Discussion}

\section{Subunit molecular weight}

In previous studies [1-4], the size and number of subunits of purified threonine dehydratase were determined by SDS-polyacrylamide gel electrophoresis with and without crosslinking with dimethylsuberimidate. When purified proteins from $E$. coli and $S$. typhimurium were reduced and alkylated according to the method of Weber et al. [11] and passed separately through a Biogel P-100 column in buffer containing $6 \mathrm{M}$ guanidine hydrochloride (Fig. 1), the proteins were eluted in discrete symmetrical peaks; from the calibration curves (not shown), the $E$. coli protein revealed a subunit molecular weight of about 38000 , whereas, 


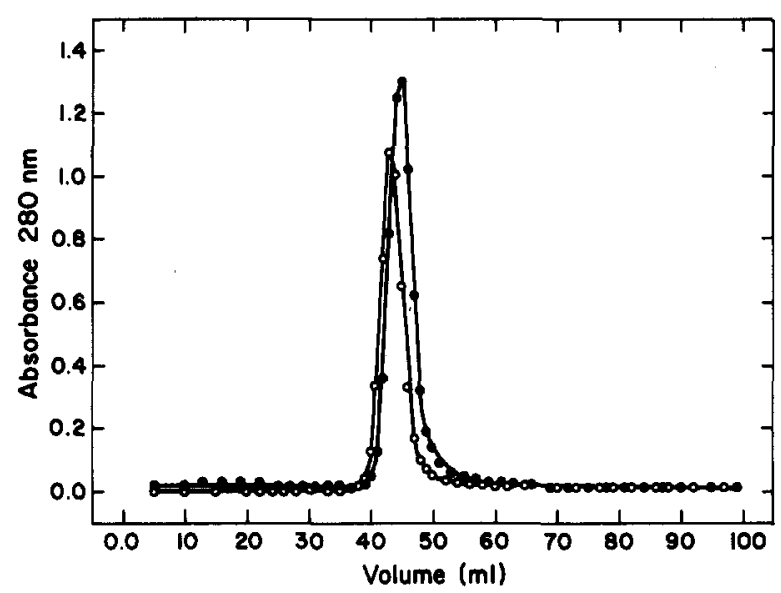

Fig. 1. Elution profile of threonine dehydratase subunits through Biogel P-100. Approx. $10 \mathrm{mg}$ of reduced and alkylated proteins from $E$. coli $(O)$ and $S$. typhimurium $(\odot)$ (see Materials and Methods) were dissolved separately in $1.5 \mathrm{ml}$ hot $0.05 \mathrm{M}$ Tris$\mathrm{HCl}$ buffer, $\mathrm{pH} 8.0$, containing $6 \mathrm{M}$ guanidine hydrochloride, cooled to room temperature and passed through an $83 \times 1.3 \mathrm{~cm}$ column of Biogel P-100 equilibrated in the same buffer at $25^{\circ} \mathrm{C}$. 1-ml fractions were collected at a flow rate of $4 \mathrm{ml} / \mathrm{h}$. The material absorbing at $280 \mathrm{~nm}$ was pooled, dialyzed exhaustively against a large excess of deionized water, and lyophilized.

the Salmonella enzyme has a slightly smaller size of 36000 . As seen in Fig. 1, no contaminating material is detected in these enzyme preparations during gel filtration in guanidine hydrochloride.

\section{Amino acid composition}

Table I shows the amino acid analyses of purified enzyme from $E$. coli and S. typhimurium. In general, the amino acid composition of the Salmonella enzyme is similar to that of $E$. coli $\mathrm{K} 12$ strain with some exceptions: the Salmonella enzyme has fewer residues of aspartic acid and serine, and more residues of glycine, isoleucine and lysine. As shown below, these differences are presumably reflected in the location and number of tryptic peptides of these proteins. It should be noted that some variations in the number of amino acid residues in enzymes of $E$. coli $\mathrm{K} 12$ (isolated in this laboratory) and $E$. coli $\mathrm{W}$ (reported by Shizuta et al. [2]) are also evident; however, it is difficult to ascertain whether these minor differences in the amino acid composition are due to analytical artifacts, or truly represent strain differences in the bacterium.
TABLE I

AMINO ACID COMPOSITION OF THREONINE DEHYDRATASES

Data for $E$. coli $\mathrm{W}$ are taken from Shizuta et al. [2].

\begin{tabular}{lccc}
\hline $\begin{array}{l}\text { Amino } \\
\text { acid }\end{array}$ & \multicolumn{2}{l}{ Residues per subunit } \\
\cline { 2 - 4 } & S. typhimurium & E. coli K12 & E. coli W \\
\hline Asp & 31 & 35 & 39 \\
Thr & 19 & 18 & 18 \\
Ser & 21 & 25 & 25 \\
Glu & 31 & 32 & 32 \\
Pro & 10 & 12 & 11 \\
Gly & 35 & 32 & 35 \\
Ala & 33 & 31 & 31 \\
Val & 31 & 30 & 28 \\
Met & 8 & 8 & 9 \\
Ile & 37 & 29 & 34 \\
Leu & 27 & 26 & 24 \\
Tyr & 10 & 9 & 8 \\
Phe & 8 & 10 & 10 \\
Lys & 22 & 18 & 20 \\
His & 7 & 7 & 7 \\
Arg & 17 & 15 & 18 \\
Tryp & 2 & 2 & 1 \\
l $/ 2$ Cys & 7 & 6 & 6 \\
& & &
\end{tabular}

\section{Tryptic peptide map}

A preliminary comparison of the tryptic peptide maps of the two dehydratases revealed that the native $E$. coli enzyme has 34 major peptides, whereas the enzyme from $S$. typhimurium has a total of 35 major peptides; based on the lysine plus arginine contents of these proteins, we expect 34-40 tryptic peptides per subunit, provided that the four subunits in each protein are identical or very nearly so.

The tryptic peptide maps of reduced and alkylated proteins from the two bacterial species are shown in Fig. 2. Despite a similar number of peptides, it is clear that, in $S$. typhimurium protein, four peptides of $E$. coli origin (peptides 6, 8, 11 and 13) are missing, whereas six peptides (designated S1 through S6) unique to Salmonella dehydratase are present. These results suggest that several peptides in the two proteins have a unique amino acid composition (also see below).

\section{Number and location of sulfhydryl groups}

The amino acid composition of the performic acid-oxidized proteins of $E$. coli and S. typhimurium 


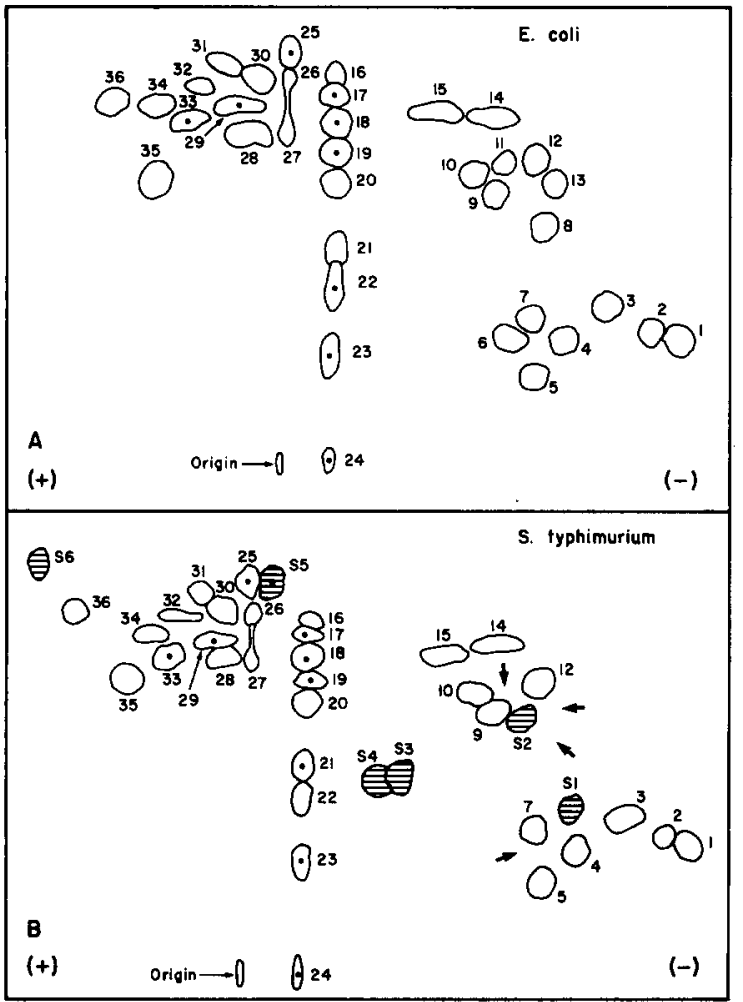

Fig. 2. Two-dimensional separation of tryptic peptides of reduced and alkylated proteins. Aliquots of enzymes, previously reduced and alkylated with sodium iodo ${ }^{14} \mathrm{C}$ lacetate and digested with TPCK-trypsin, were subjected to two-dimensional separation as described in Materials and Methods. (A) E. coli enzyme, $365 \mu \mathrm{g}$. (B) $S$. typhimurium protein, $350 \mu \mathrm{g}$. In panel $B$, the heavy arrows show the location of the missing peptides observed in $E$. coli finger prints, whereas, the 'striped' spots indicate new peptides unique to Salmonella enzyme. The peptides with solid 'dots' in the center are those which contain radioactivity; these were identified by exposing the dry plates to Kodak X-ray films for $\mathbf{4 8 ~ h}$ and superimposing the autoradiographs on the thin-layer plates. The numbering of peptides was adopted to indicate their similar migration behavior.

shows 24 and 28 half-cystine residues, respectively, per mol protein (cf. Table I). The titration of free -SH groups in the native protein in the presence of AMP reveals that the $E$. coli enzyme has 24 free -SH groups (indicating no disulfide linkage), and only 12-16 -SH groups are reacted in the absence of AMP [23]. The Salmonella enzyme, on the other hand, has a total of 16 free -SH groups per mol protein (four of which are 'buried' in the protein interior and reacted with 5,5'-dithiobis(2-nitro- benzoate) only in the presence of $0.15 \%$ SDS [4]), suggesting the presence of several disulfide bonds. The tryptic peptide maps displayed in Fig. 2 were obtained by carboxymethylation of enzymes in the presence of iodo $\left[{ }^{14} \mathrm{C}\right]$ acetate, and the labeled peptides, identified by autoradiography, are marked with a solid 'dot' in the center. It is evident from the data that eight peptides in the two proteins exhibiting similar migration behavior are radioactively labeled; on the other hand, peptide S5 of $S$. typhimurium, which has no equivalent peptide in $E$. coli, and peptide 21 contain radioactivity, whereas peptide 22 of $E$. coli enzyme is radioactive.

Because the total number of half-cystine residues in these enzymes is different ( 24 in $E$. coli and 28 in $S$. typhimurium), and there are more sulfhydryl groups in each protein than there are labeled peptides, a quantitative estimation of radioactivity bound to the peptides was made by scraping off the spots from thin-layer plates and counting for radioactivity. As shown in Table II, with the expection of peptides 17, 18, 19 and 24, all peptides of the $S$. typhimurium enzyme have higher counts than their counterparts in the $E$. coli enzyme; peptides 18, 19 and 24 from both enzymes have similar counts, whereas peptides 17 of the $E$. coli enzyme has more radioactivity as compared to the same peptide of the $S$. typhimurium dehydratase. From the total number of half-cystine residues in each protein and the total counts recovered, it is possible to approximate the relative distribution of the number of sulfhydryl groups present in each peptide (see Table II). These results are consistent with the notion that some tryptic peptides in these proteins have a unique half-cystine content and, therefore, have different primary structures despite their similar migration patterns in the two-dimensional separation system.

\section{Amino terminus sequence}

From the tryptic fingerprints and sulfhydryl determination it appears that the dehydratases purified from the two bacterial species have some differences in the amino acid sequence in specific regions of the molecules. However, the results presented in Fig. 3 clearly reveal that of the 25 amino acid residues in the amino termini of these proteins only three are different, indicating a highly 


\section{TABLE II}

\section{QUANTITATION OF BOUND RADIOACTIVITY TO TRYPTIC PEPTIDES}

Purified enzymes from $E$. coli and $S$. typhimurium, reduced and alkylated in the presence of sodium iodo $\left[{ }^{14} \mathrm{C}\right]$ acetate, were digested with TPCK-trypsin and the peptides separated by the two-dimensional procedure as described in Materials and Methods. For identification of radioactive peptides, see legend to Fig. 2. For quantitation of radioactivity, the cellulose from each radioactive spot was carefully scraped off, suspended in the scintillation fluid and counted for radioactivity. Approx. $350 \mu \mathrm{g}$ protein containing 150000 cpm were applied to each plate, and the total counts recovered were 70093 and 59236, respectively, in the labeled peptides from $S$. typhimurium and $E$. coli. Approx. $30 \%$ of radioactivity remained at the origin. The relative number of sulfhydryl residues in the peptides was estimated by asśuming $2500 \mathrm{cpm}$ per residue (obtained by dividing the total counts recovered in all peptides by the total number of half-cystine residues found in each protein from amino acid analysis). ST, S. typhimurium; EC, E. coli

\begin{tabular}{|c|c|c|c|c|c|}
\hline \multirow{2}{*}{$\begin{array}{l}\text { Peptide } \\
\text { No }\end{array}$} & \multirow{2}{*}{$\begin{array}{l}\text { S. typhimurium } \\
\text { (cpm) }\end{array}$} & \multirow{2}{*}{$\begin{array}{l}\text { E. coli } \\
\text { (cpm) }\end{array}$} & \multirow{2}{*}{$\begin{array}{l}\text { Ratio } \\
\text { of cpm } \\
\text { ST / EC }\end{array}$} & \multicolumn{2}{|c|}{ SH- residues } \\
\hline & & & & $\overline{\text { ST }}$ & $\mathrm{EC}$ \\
\hline 17 & 2306 & 6225 & 0.37 & 0.92 & 2.5 \\
\hline 18 & 17710 & 18003 & 0.98 & 7.1 & 7.2 \\
\hline 19 & 8334 & 8106 & 1.03 & 3.3 & 3.2 \\
\hline 21 & 4342 & - & - & 1.7 & - \\
\hline 22 & - & 4356 & - & - & 1.7 \\
\hline 23 & 3731 & 2814 & 1.33 & 1.5 & 1.1 \\
\hline 24 & 1712 & 1525 & 1.12 & 0.69 & 0.61 \\
\hline 25 & 5186 & 2279 & 2.28 & 2.1 & 0.91 \\
\hline 29 & 13230 & 10492 & 1.26 & 5.3 & 4.2 \\
\hline 33 & 8455 & 5436 & 1.56 & 3.4 & 2.2 \\
\hline S5 & 5087 & - & - & 2.0 & - \\
\hline
\end{tabular}

conserved structure at the amino terminus end; in each of these residues, a single base change can result in the observed amino acid substitution. Without the complete amino acid sequence data of the two proteins it is difficult to ascertain just which parts of the molecules have divergent primary structure. It should be noted in this context that the amino terminus sequence of the dehydratase isolated from $E$. coli strain W, as reported by Saeki et al. [3], is identical to that of the enzyme purified in this laboratory from $E$. coli K12 strain (see Fig. 3).

\section{Nucleotide requirement}

The activity of threonine dehydratase is stimulated by AMP, and the concentration of AMP required for one-half the maximal velocity is 70 $\mu \mathrm{M}$ and $50 \mu \mathrm{M}$, respectively, for enzymes from $E$. coli and $S$. typhimurium [2,4]. The Scatchard plot of AMP binding to the Salmonella enzyme, as shown in Fig. 4, reveals four non-interacting AMP binding sites per $140000 \mathrm{~g}$ with a $K_{\mathrm{A}}$ value of 30 $\mu \mathrm{M}$; similar results have been reported for the enzyme isolated from $E$. coli [2]. Thus, the two proteins are similar with respect to the number of sites and association constant for AMP binding. On the other hand, the dehydratase from $S$. typhimurium, but not from $E$. coli, can also bind ADP for stimulation of enzyme activity [4].

\section{Pyridoxal phosphate binding site}

Phillips and Wood [24] have proposed a mecha-
E. coli $\mathrm{k} 12$ :
$\stackrel{5}{5} \stackrel{10}{0}$
10
1520
25
S. typhimurium: Met-His-Ile-Thr-Tyr-Asp-Leu-Pro-Val-Ala-Ile-G1u-Asp-Ile-Leu-Glu-Ala-Lys-Lys-Arg-Leu-Ala-G1y- ? -I le

Fig. 3. Amino terminus sequence of the biodegradative threonine dehydratases. Automated sequence analyses of the reduced and alkylated proteins isolated from $E$. coli $\mathrm{K} 12$ and $S$. typhimurium LT2 were performed as described in Materials and Methods. 


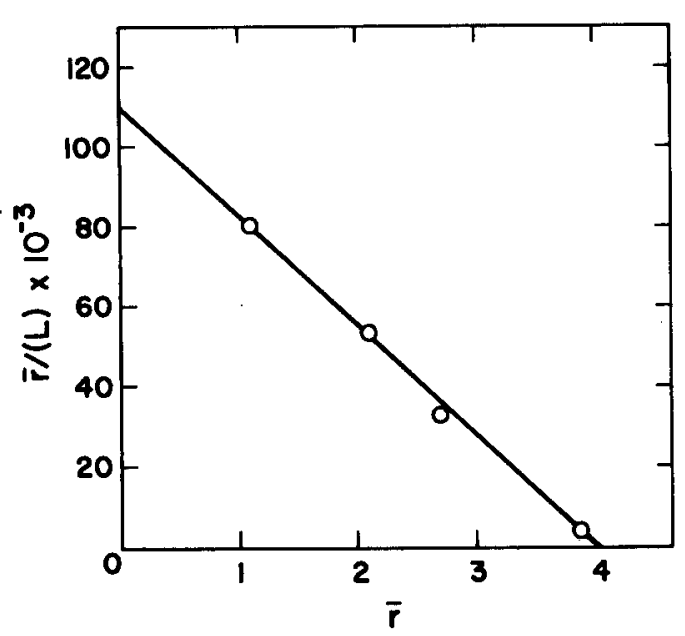

Fig. 4. Binding of AMP to threonine dehydratase of $S$. typhimurium. The binding of $\left[{ }^{14} \mathrm{C}\right] \mathrm{AMP}$ was determined by equilibrium dialysis at $4^{\circ} \mathrm{C}$ as described in Materials and Methods. The data are plotted according to Scatchard [20], where $r=\mathrm{mol}$ AMP bound per mol enzyme, and $[L]=$ concentration of free AMP.

nism for dehydration of L-threonine which involves enzyme-bound pyridoxal phosphate in Schiff base to an $\epsilon$-amino group of a lysine residue. According to Shizuta et al. [2], the E. coli W dehydratase have $4 \mathrm{~mol}$ pyridoxal phosphate per tetramer. Recently, Park and Datta [25] have shown that in $E$. coli $\mathrm{K} 12$ only 2 mol pyridoxal phosphate are bound in Schiff base absorbing at $413 \mathrm{~nm}$, and are catalytically active; the other two pyridoxal phosphates, not involved catalytically and not absorbing at $413 \mathrm{~nm}$, either occupy sites on the protein having a different physical environment or exist in a somewhat altered chemical state. With the enzyme from $S$. typhimurium only $2 \mathrm{~mol}$ pyridoxal phosphate are bound per $140000 \mathrm{~g}$ [4]. To examine the identity of the active-site peptide(s) which contains pyridoxal phosphate, purified enzymes of $E$. coli and $S$. typhimurium were reduced separately with sodium $\left[{ }^{3} \mathrm{H}\right]$ borohydride, digested with trypsin and the peptides were separated by electrophoresis and chromatography on thin-layer plates. When analyzed for radioactivity, only one peptide in each case, having a similar migration pattern, has significant amounts of counts indicating covalently bound pyridoxal phosphate. This result appears to suggest that the two classes of bound pyridoxal phosphates in the $E$. coli enzyme, although non-equivalent in nature, reside on the same tryptic fragment.

\section{Modifier binding peptides}

We have reported earlier $[4,9,10]$ that threonine dehydratases of $E$. coli and $S$. typhimurium are subject to catabolite inactivation by several intermediary metabolites, notably pyruvate and glyoxylate. During incubation with pyruvate, 1 mol pyruvate per mol protein becomes covalently attached to the enzyme causing enzyme inactivation $[4,10]$. With glyoxylate, on the other hand, there is a rapid covalent binding of $1 \mathrm{~mol}$ glyoxylate per tetramer (designated monoglyoxylated form of the enzyme) followed by a slow binding of 3 additional mol glyoxylate for a total of $4 \mathrm{~mol}$ per mol tetrameric protein $[9,25]$. To decide which peptide(s) binds these metabolites, purified enzyme from $S$. typhimurium was treated separately with ${ }^{14} \mathrm{C}$-labeled ligands, reduced and alkylated with unlabeled iodoacetate, and the peptides were separated using the two-dimensional procedure after digestion with trypsin (see Materials and Methods). Upon autoradiography of the thin-layer plate containing $\left[{ }^{14} \mathrm{C}\right]$ pyruvate-treated enzyme, only one major radioactive spot, corresponding to peptide 17 (cf. Fig. 2), was visible. When the cellulose from this spot was scraped off and counted, approx. $17000 \mathrm{cpm}$ was recovered, representing slightly greater than $50 \%$ of the radioactivity applied to the thin-layer plate. Small amounts of radioactivity less than $15 \%$ of total, were also found to be distributed in several other peptides, especially in peptides 16 and 18, presumably due to incomplete separation; approx. 20\% of the total radioactivity remained bound at the origin. Autoradiographic analyses of the glyoxylate-treated enzyme from $S$. typhimurium show that only peptides 22 (see Fig. 2) was labeled upon incubation with $\left[{ }^{14} \mathrm{C}\right]$ glyoxylate for less than $60 \mathrm{~min}$ (yielding monoglyoxylated form of the enzyme), and both peptides 22 and 21 contained radioactivity after long-term incubation with $\left[{ }^{14} \mathrm{C}\right]$ glyoxylate. Experiments are in progress to isolate these peptides for determination of their complete amino acid sequence. 
TABLE III

A COMPARISON OF SOME OF THE PROPERTIES OF BIODEGRADATIVE THREONINE DEHYDRATASES FROM TWO ENTERIC BACTERIA

\begin{tabular}{|c|c|c|c|c|}
\hline Properties & E. coli & Ref. & S. typhimurium & Ref. \\
\hline Molecular weight & 147000 & 1,2 & 140000 & 4 \\
\hline $\begin{array}{l}\text { Number and subunit } \\
\text { molecular weight }\end{array}$ & $4(38000)$ & $1-3^{a}$ & $4(36000)$ & $4^{a}$ \\
\hline Pyridoxal phosphate & & & & \\
\hline content $/ \mathrm{mol}$ protein & 4 & $2,9,25$ & 2 & 4 \\
\hline Number of free -SH & & & & \\
\hline groups /mol protein & 24 & 2,23 & 16 & 4 \\
\hline $\begin{array}{l}\text { Number of half-cystine } \\
\text { residues /mol protein }\end{array}$ & 24 & $2,3^{a}$ & 28 & $-^{a}$ \\
\hline AMP concentration for & & & & \\
\hline $\begin{array}{c}V_{\max } / 2 \\
\text { Number of AMP binding } \\
\text { site } / \text { mol protein and }\end{array}$ & $70 \mu \mathrm{M}$ & 2,9 & $50 \mu \mathrm{M}$ & 4 \\
\hline$K_{\mathrm{m}}$ for L-threonine & $4(10 \mu \mathrm{M})$ & 2 & $4(30 \mu \mathrm{M})$ & $-{ }^{a}$ \\
\hline (no AMP) & $70 \mathrm{mM}$ & $1,2,9$ & $125 \mathrm{mM}$ & 4 \\
\hline $\begin{array}{l}K_{\mathrm{m}} \text { for L-threonine } \\
\text { (with AMP) }\end{array}$ & $3 \mathrm{mM}$ & $1,2,9$ & $8 \mathrm{mM}$ & 4 \\
\hline $\begin{array}{l}\text { Ratio of } V_{\max } \text { with } \\
\text { and without AMP }\end{array}$ & 1 & 1 & 6 & 4 \\
\hline Stimulation by ADP & No & 2 & Yes & 4 \\
\hline $\begin{array}{l}\text { Pyruvate inhibition } \\
\text { kinetics with respect } \\
\text { to L-threonine }\end{array}$ & $\begin{array}{l}\text { Uncompetitive } \\
\text { and substrate } \\
\text { inhibition }\end{array}$ & 8 & Noncompetitive & 4 \\
\hline $\begin{array}{l}\text { Pyruvate inhibition } \\
\text { kinetics with respect } \\
\text { to AMP }\end{array}$ & Noncompetitive & 8,9 & Mixed & 4 \\
\hline
\end{tabular}

Data from this study.

\section{Conclusion}

Although the biodegradative threonine dehydratases from the two enteric bacteria have overall similarities in their catalytic properties and are subject to the same types of regulation by intermediary metabolites, the results described herein and those published previously indicate that these two proteins are different from each other in their detailed chemical architecture. As summarized in Table III subtle differences are seen in terms of molecular weights of the native enzyme, subunit size, number and mode of binding of coenzyme, the number and location of half-cystine residues and the presence of disulfide bonds, and interactions with nucleotide effectors. Because of these findings, and the close phylogenetic relationships of the two bacterial species with overall DNA sequence homology [26,27], a careful analysis of the chemical and physical organization of the enzymes is needed to gain an insight into the molecular evolution of protein structure.

\section{Acknowledgement}

This work was supported by the U.S. National Institutes of Health grant GM 21436. We thank Drs. George E. Tarr and Charles H. Williams, Jr. for their assistance in the amino terminus sequence determination using the equipment purchased, in part, through the U.S. National Institutes of Health grant GM 27558.

\section{References}

1 Whanger, P.D., Phillips, A.T., Rabinowitz, K.W., Piperno, J.R., Shada, J.D. and Wood, W.A. (1968) J. Biol. Chem. $243,167-173$ 
2 Shizuta, Y., Nakazawa, A., Tokushige, M. and Hayaishi, $O$. (1969) J. Biol. Chem. 244, 1883-1889

3 Saeki, Y., Ito, S., Shizuta, Y., Hayaishi, O., Kagamiyama, H. and Wada, H. (1977) J. Biol. Chem. 252, 2206-2208

4 Bhadra, R. and Datta, P. (1978) Biochemistry 17, 1691-1699

5 Wood, W.A. and Gunsalus, I.C. (1949) J. Biol. Chem. 181, 171-182

6 Luginbuhl, G.H., Hofler, J.G., Decedue, C.J. and Burns, R.O. (1974) J. Bacteriol. 120, 559-561

7 Shizuta, Y., Kurosawa, A., Inoue, K., Tanabe, T. and Hayaishi, O. (1973) J. Biol. Chem. 248, 512-520

8 Park, L.S. and Datta, P. (1979) J. Bacteriol. 138, 1026-1028

9 Park, L.S. and Datta, P. (1979) J. Biol. Chem. 254, 79277934

10 Feldman, D.A. and Datta, P. (1975) Biochemistry 14, 1760-1767

11 Weber, K., Pringle, J.R. and Osborn, M. (1972) Methods Enzymol. 26, 3-27

12 Blackburn, S. (1968) Amino Acid Determination, Methods and Techniques, Marcel Decker, New York

13 Bencze, W.L. and Schmid, K. (1957) Anal. Biochem. 29,1193-1196

14 Janatova, J., Fuller, J.K. and Hunter, M.J. (1968) J. Biol. Chem. 243, 3612-3622
15 Ramachandran, N. and Colman, R.F. (1978) Proc. Natl. Acad. Sci. U.S.A. 75, 252-255.

16 Gracy, R.W. (1977) Methods Enzymol. 47, 195-204

17 Dryer, W.J. and Bynum, E. (1967) Methods Enzymol. 11, 32-39

18 Brauer, A.W., Margolies, M.N. and Haber, E. (1975) Biochemistry 14, 3029-3035

19 Kohlmiller, N.A. and Howard, J.B. (1979) J. Biol. Chem. 254, 7302-7308

20 Scatchard, G. (1949) Ann. N.Y. Acad. Sci. 51, 660-672

21 Fluri, R., Jackson, L.E., Lee, W.E. and Crawford, I.P. (1971) J. Biol. Chem. 246, 6620-6624

22 Lowry, O.H., Rosebrough, N.J., Farr, A.L. and Randall, R.J. (1951) J. Biol. Chem. 193, 265-275

23 Tokushige, M. (1970) Seikagaku 42, 887-903

24 Phillips, A.T. and Wood, W.A. (1965) J. Biol. Chem. 240, 4703-4709

25 Park, L.S. and Datta, P. (1981) J. Biol. Chem. 256, 53625367

26 Brenner, D.J. and Falkow, S. (1971) Adv. Genet. 16, 81-118

27 Sanderson, K.E. (1976) Annu. Rev. Microbiol. 30, 327-329 